\title{
Adaptation of Culture and Creative Industries Sphere to the Transition of Digital Technologies
}

\author{
Sukhovskaya D.N.* Ermakova L.I.
}

\author{
Pyatigorsk State University, Pyatigorsk, Russia \\ *Corresponding author. Email: daria.sukhovskaya@yahoo.com
}

\begin{abstract}
The article presents the analyses of the operational model of managing culture organizations and business of the creative industries sector and also examines the problems emerging in the process of the adaptation of culture and creative industries to the transition to digital technologies. The authors describe the effects of the impact of the transition to digital technologies on the value creation chain in creative industries. The work offers the description of the process of value creation in the creative economy taking into account the effect of the online-culture and digital culture on creative industries as a whole.

Keywords: creative economy, culture and creative industries, creative space, value creation chain, online-
\end{abstract}

culture, digital culture, operational management models

\section{INTRODUCTION}

In the modern practice of managing creative spaces there emerges a number of problems relating to the definition of the ways of realization of corporate strategy in company's day-to-day activities, i.e. operational modes of they or that business of the creative sector of the economy. The indicated problems acquire special topicality in the $21^{\text {st }}$ century in the context of the adaptation of culture sphere to the transition to digital technologies. To carry out the analyses of the aforesaid problems it in necessary to examine a number of notions and definitions which characterize the phenomena and processes now in program in the creative economy.

The notion «creative economy» is defined as the totality of individuals and business which create culture, artistic and innovative products and services [1]. This system also includes creative spaces where the manufacturers of culture products and services can freely present their works, get a reviews and exchange ideas [2].

In the sphere of culture and creativeness it is necessary to speak about a culture product. Having analyses the term «culture product» in various aspects of activity one can draw a conclusion, that culture product is:

1) the good provided by culture intuitions in the form of good and services that bear in themselves culture values, meanings, ideas, ethical and moral norms, images, culture codes and conceptions [3];

2) the results of the process of ideals-formation personalized in the material (as a representative) or immaterial (as an ideal) form, intended to meet the needs of the highest order (secondary, i.e. social, spiritual, communicative, etc.) [4].
Topical within this research in the notion «value creation chain» which in understand as a chain within which every successive organization adds value for the customer who gets the end culture product [5]. From the practical viewpoint the value creation chain can be illustrated on the example of the organization of a performance.

The process of staging a play starts with the author of the play and their manuscript guarantee the creative component of the project. In the process of the work on the production, the process involves the theatre company which creates the interpretation of the author's text and stages the play. The staging of the play requires the work of designers, artists, scenery artist, person in charge of lighting effects and other specialists, and also premises for rehearsals and performance. Thus, the manuscript is supplemented by the links of the value creation of a culture product, in this case-play, the chain involves the organization in charge of the realization of culture product, i.g. ticket service on the Internet. The example, enables us to illustrate the process of the transformation of the creative idea to a culture product through the value creation chain [6].

\section{METHODOLOGY}

The methodology of the research is based on the sociological methods of analysis in the information society, including interviews, work with the focus groups, study of the statistical research and surveys.

In the conducted research, the proliferation of innovations was studied on the example of the words connected with new technologies, goods, services and formats of activity. 
Research included the analysis of the external and local Internet-image of culture organizations of Novosibirsk, Ekaterinburg, Voronezh, Tomsk, Tyumen, Krasnodar, Belgorod which (with the exception of Voronezh) are in the group of the city-leaders by the development of human potential. The external image was studied on the example of the media news feed and the local - on the example of the feed of publications in the social network "Vkontakte".

\section{RESULTS AND DISCUSSION}

\subsection{Operational models of managing culture organization and creative spaces}

Let as examine the three operational models of managing culture organizations and creative spaces.

The first mode is based on the project-bused activity [7]. The project in the sphere of culture and creative industries is a sphere of the activity in in the course of which are determined and achieved the clear goals balancing between the scope of work, and resources (such as money, work, materials, energy, space, etc.), time, quality and risks. Culture projects may be similar, may resemble each other, but, as a rule, each project is unique. Rather often culture organizations, especially small ones, work with a number of project, they seek financing from grant giver or sponsors, and then they launch the project, realize it and pass on to the next one. Small business of the creative sector may realize several projects simultaneously.

In example of the organizations that refer to their model are, for example, the interactive mass media, the companies realizing projects to develop computer games, mobile content, etc. [8].

The second model are organizations, specializing in the creation of culture products or providing culture services (advertising agencies, film companies, theatre companies, designers and others) [9].

The third model of the operation of culture organizations and creative business is a mixed one: organizations operating within the indicated model have culture products to all on the market, and they are also involved in the realization of the product [10]. In example of this operational model are theatres that have permanent repertoire but at the same time they realize the project within which they develop and create a new production.

\subsection{Problems of operational models of managing culture organizations and creative spaces}

Let as examine the main problems that the organizations of the creative economy sector dealing with these three different operational models are faced with.
The first problem that the organization working with products and projects faces is the difference between them. The differences in the type of the projects, realized, by the organizations of the culture industries sector, raises the complexity of managing them, as different project require a different resource base for their realization [11].

The second problem that culture organizations and creative businesses face is a great number of projects and, as a result, the high complexity of managing them. The effective way of the solution of the problem is to develop projects portfolio which enables one to differential between the internal projects (the projects which organization realizes on its own) and external projects (the projects financed from external sources: at the expense of grants, sponsors, crowdfunding or by the combination of the aforesaid forms of financing [12].

The third problem - the transition from project to product and services. An example of this is the situation when project organizations develop a great number of projects but, incidentally, they do not know how to enter a market to sell new products or services they specialize in [13].

\subsection{The effects of the impact of the transition to digital technologies on the value creation chain in creative industries}

In the modern world with the abundance of gadgets and the possibility of obtaining diverse content on the Internet, consumers are capable of changing the forms of culture produce consumption [14]. The trends of the development of online-culture influence the formations of the value creation chain in different segments of the creative industries sector [15].

One of the effects of the impact of the transition to digital technologies on the value creation chain and creative industries in the extension of access to information. In the age of digital technologies the manufactures of culture and creative goods and services need to obtain credible knowledge of the sources of information used by potential consumers, what e-platforms and gadgets consumers use, this also effects the way how and where the culture project should be accessible to consumers [16]. It is not only about then behavior but also about the information resources on which consumers get culture produce. To ensure the effective management of the organization of the creative economy sector especially topical is the work with such channels of distribution of culture goods and services as for example KudaGo.com - the service to promote events and entertainments in Russia's cities (Moscow, St. Petersburg, Kazan, Novorossiysk and others), and also in the similar services on the Internet: Moscow's free interactive poster - 2DO2GO.RU, «Afisha», kudamoscow.ru and others [17].

The second effect of the transition to digital technologies is the change in the culture of the consumption of the produce of creative industries [18]. Prior to the mass proliferation of digital technologies the product and the 
source were in the obvious interaction, at present we are seeing the trend towards the universalization of the sources of the provision of culture product, hereby a new culture of the consumption of culture content is being formed (e.g. earlier consumers used to go to the movies to consume such culture product as film, nowadays they can go to the movies to watch the online-broadcaster ballet or opera from the world-famous theatre, etc.) [19].

The third charge affecting the value creation chain and creative economy is the promotion of goods and services. Within the current trend the focus is on the issues of how the operators the participants in the value creation chain find new clients, what sources of information and gadgets are available who changes their culture, in what particular way culture produce is consumed, so, the strategies of produce promotion also need to be adapted to the digital changes now under way in society [20].

Coming back to the original notion of the value creation chain we can see that the consumers of culture goods and services change as well as the ways of produce proliferation. This means that the business people of the creative sector have to adapt themselves because the ultimate link of the value creation chain changes very quickly, so do the participants in this chain, it becomes broken. The people of the creative professions also need to adapt themselves and so they do - some of them simply make their sounds of publishers, distributors and a direct contact with consumers, as you know, they can realize the manufactured culture product all on their own and they have social networks for his promotion [21].

One of the main and obvious effects of the transition to the digital technologies of the value creation chain is the emergence of the promotions (Facebook, Twitter, Instagram, Vkontakte) and the creative goods distribution centers (platforms Amazon.com, Google Play, App Store) [22]. Platforms dominate the market of culture and creative goods and services thus enabling them to attract the audience of the potential consumers of goods and services by using new, interactive formats, video, multimedia experiments to attract the audience to the culture product. Drawing on this we can make a conclusion that the business model in the culture and creative industries sector should hath employ these platforms and, essentially, compete with them. The employment of the platforms is connected with their broad proliferation in modern society and also with their growing efficiency. On the other hand, platforms need to be competed with, as the most valuable clients are those with whom the organization can establish direct links (subscribers to newsletters, users of the organization's application). Proceeding from this organizations should not limit themselves to working exclusively with platforms as, you know, in this case they start controlling the value creation chain [23].

The transitions to digital technologies also reflected business processes: production of culture product, marketing, sales, after-sale work with clients. Even speaking about «cultural» in some sense, businessprocesses, themselves, such as presentation of works of art or museification, or analyses of digitizing the work of art, it should be noted, that digital technologies are available here as well: much is currently being converted to the digital factor, and marketing work necessary the use of certain methods, platforms and software [24]. Businessprocess now in progress on modern organizations of the culture and creative industries sector should supplement each other, and the analogous business-process should be converted to digital ones as this meets the needs of the customer base.

\section{CONCLUSION}

Proceeding from the analyses of the operational models of managing culture organizations and business of the culture industries sector and also the problems emerging in the process of the adaptation of culture and creative industries to the transition to digital technologies, and also the description of the value creation process in the creative economy taking into account the impact of online-culture one can conclude that the changes typical of the modern culture consumption need the adaptation of all the aspects of the work of the organizations of the culture and creative industries sector by introducing projects portfolio, transforming project to products and services.

\section{REFERENCES}

[1] H.A.M. Ramli, R.F. Mayana, T. Santika, Fostering a creative economy with copyright protection: "Weightless economy" and creativity-based sustainable development. 2020. International Journal of Innovation, Creativity and Change. 10(10), pp. 432-443.

[2] L. Ermakova, D. Sukhovskaya, Creative Spaces of Cities as Platforms of the Fourth Technological Information Revolution._Lecture Notes in Networks and Systems. 2020, pp. 687-693. DOI: 10.1007/978-3-03015160-7_69

[3] D.N. Sukhovskaya, Thesaurus approach to the determining of the essence of a creative area of a modern city, European Social Science Journal. 2013, No 11-1(38). pp. 291-297.

[4]E. Strom, Revisiting the arts as a socially innovative urban development strategy. 2020. European Planning Studies. 28(3), 2 pp. 475-495. DOI: $10.1080 / 09654313.2019 .1639398$

[5] L. Ermakova, D. Sukhovskaya, Value Orientations of the Information Society in the Context of the Information Revolution of the 21st Century. Lecture Notes in Networks and Systems. 2020, pp. 577-584. DOI: 10.1007/978-3-03015160-7_58 
[17] D. Sukhovskaya, Creative area of Russian urban

[6] L. Ermakova, D. Sukhovskaya, Information Age: Intellectual Leisure of a Modern Town-Dweller. 2020. Lecture Notes in Networks and Systems, pp. 647-654. DOI: $10.1007 / 978-3-030-15160-7 \_65$

[7] L.M. Weber, A. Loumakis, Ja. Bergman, Who participates and why? An analysis of the Internet and the mass public, Social Science Computer Review. Vol. 21. No 1. pp. 26-42. DOI: 10.1080/02732170590925882

[8] O. Bates, C. Remy, C. Nash, B. Kirman, The future of techno-disruption in gig economy workforces: Challenging the dialogue with fictional abstracts. 2019. ACM International Conference Proceeding Series 3363476. DOI: $10.1145 / 3363384.3363476$

[9] C. Antonelli, C. Feder, The new direction of technological change in the global economy. 2020. Structural Change and Economic Dynamics. 52, pp. 1-12. DOI: $10.1016 /$ j.strueco.2019.09.013

[10] W. Ihani, H. Syofya, A.L. Sari, The role of the creative industry in economic development. 2020. Journal of Environmental Treatment Techniques. 8(1), pp. 268271.

[11] P. Kurniawan, W. Hartati, S.L. Qodriah, B. Badawi, From knowledge sharing to quality performance: The role of absorptive capacity, ambidexterity and innovation capability in creative industry. 2020. Management Science Letters. $10(2), \quad$ pp. 433-442. DOI: $10.5267 /$ j.msl.2019.8.027

[12] L. Ermakova, D. Sukhovskaya, Creative industries and areas as tools of global crisis management. 2017. Contributions to Economics (9783319606958), pp. 335340. DOI: 10.1007/978-3-319-60696-5_43

[13] J.A.C. Pereyra, Entrepreneurship and the city. 2019. Geography

DOI: $10.1111 / \mathrm{gec} 3.12471$

Compass.13(12),e12471.

[14] F. Colace, M. De Santo, Ontology for e-learning: a Bayesian approach, IEEE Transactions on Education. 2010. Vol. 53. No 2 . pp. 223-233. DOI: 10.1109/TE.2009.2012537

[15] E.A. Goryacheva, Personality in the age of information technology, in Wschodnie partnerstwo - 2015. Materials of the XI international scientific conference, Moscow, 2015, pp. 64-66.

[16] M. Danet, R. Miljkovitch, The virtual world: attachment-related issues and risks, Psychologie Francaise. 2017. Vol. 62. No 1. pp. 57-83. DOI: 10.1016/j.psfr.2015.10.002 settlements and its influence on the formation of a personality's value-based orientations, Krasnodar University of the Ministry of Internal Affairs of the Russian Federation. 2017.

[18] J. James, The global digital divide in the Internet: developed countries constructs and third world realities, Journal of Information Science. 2005. Vol.31. No 2. pp. 114-123.

[19] E. Kurilovas, S. Kubilinskiene, V. Dagiene, Web 3.0 - based personalization of learning objects in virtual learning environment, Computers in Human Behavior. 2014, Vol. 30. pp. 654-662. DOI: $10.5815 /$ ijmecs.2014.02.02

[20] L. Mozheikina, P. Emelyanov, Personal issues of social networks: towards safe surfing, in WMSCI 2016 20th World Multi-Conference on Systemics, Cybernetics and Informatics, Proceedings 20, Moscow, 2016, pp. 260265.

[21] N.S. Malieieva, The role of social networks in the function of information and communication technologies in the modern society, in Problems of development of a personality: diversity of approaches. Materials of the IV international scientific conference, Moscow, 2017, pp. 2528. DOI: $10.5281 /$ zenodo. 1512122

[22] Y. Zagorulko, G. Zagorulko, Ontology-based technology for development of intelligent scientific Internet resources, Communications in Computer and Information Science. 2015, Vol. 532. pp. 227-241. DOI: $10.15826 /$ icrt.2018.01.2.16

[23] F. Colace, M. De Santo, Ontology for e-learning: a Bayesian approach, IEEE Transactions on Education. 2010, Vol. 53. No 2. pp. 223-233. DOI: 10.1109/TE.2009.2012537

[24] N. Hasti, , G. Kusnia, Role of Technology for Interior Design Sectors in Creative Economic Development. 2019. IOP Conference Series: Materials Science and Engineering 662(4),042027. DOI: $10.1088 / 1757-899 X / 662 / 4 / 042027$ 